\title{
Outcomes of Learning Online: The Case of Farmers and Extension Workers in the Philippines
}

\author{
Marjhurhy Ann S. Federicos and Rotacio S. Gravoso
}

Department of Development Communication, Visayas State University, Baybay City, Leyte 6521-A Philippines

\begin{abstract}
The Philippines is now adopting information and communication technology (ICT) to promote agricultural sustainability and rural development. Among the development programs that apply ICT is the Open Academy for Philippine Agriculture (OPAPA) E-Learning Project by the Philippine Rice Research Institute (PhilRice), the agency mandated to spearhead research and development programs on rice. Following the most significant change (MSC) technique, this study was conducted to identify the most significant changes experienced by OPAPA E-Learning graduates composed of farmers, extension workers and agricultural science students. Results showed that respondents enrolled in the program to acquire knowledge of rice technologies, gain skills in operating a computer, update themselves about new farm technologies, and comply with academic and work requirements. Based on $20 \mathrm{MSC}$ stories collected, the OPAPA E-Learning Project has led to the increase in knowledge of rice technologies and awareness of the program, improvement in school, farm and extension practices, and enhancement of computer skills. The Bennett Hierarchy of Program Outcomes revealed that the most significant change stories reported by the respondents correspond to higher levels of outcomes, indicating that the OPAPA E-learning Project has already made an impact in terms of improving its clientele's knowledge and capability.
\end{abstract}

Key Words: distance learning, most significant changes, capability development,agricultural technologists, rice production

Correspondence: R. S. Gravoso. Address: Visayas State University, Baybay City, Leyte 6521-A Philippines.E-mail: gravoso@gmail.com.

DOI: $10.32945 /$ atr3418.2012 


\section{INTRODUCTION}

Information and communication technology (ICT) plays an important role in rural and agricultural development. According to the International Institute for Communication and Development (IICD), use of ICT in rural development initiatives helps improve the incomes of small-scale farmers and the efficiency of the agricultural sector. More specifically, ICT is useful in providing information to farmers on inputs, market prices, and supply and demand, and bridges the gap between researchers and farmers by exchanging scientific and experience-based information about traditional and modern production techniques (IICD, 2005).

Studies have demonstrated that in many developing countries, use of ICT facilitated attainment of development goals. Accordingly, ICT has helped improve knowledge flows and more cost-effectively widened the participation of stakeholders in the research process (Thas and Simerska, 2006).

In the Philippines, some agencies have been applying ICT to promote agricultural sustainability and rural development. Among these is the Philippine Rice Research Institute (PhilRice), the agency mandated to spearhead research and development (R\&D) related to rice production in the Philippines. Since 2000, PhilRice has been implementing the Open Academy for Philippine Agriculture (OPAPA). OPAPA aims to: 1) educate, train, and mobilize the extension workers in agriculture using ICT and distance learning to bring about agricultural modernization; 2) package available information and farming technologies into relevant electronic or digitized formats for use by all farming stakeholders; and 3) provide extension services, advisory and general information on agriculture to farmers (OPAPA Completion Report, 2008).

For the five years that it has been operating, the OPAPA E-learning Project has produced and implemented learning modules on rice and ricebased production systems (OPAPA Completion Report, 2008). As of 2008, about 55 college students, extension workers, farmers, teachers, and overseas Filipino workers (OFWs) have enrolled in the program.

Studying through the OPAPA E-learning Project provides the clientele with an opportunity to directly contact experts through virtual communication and exchange of ideas between experts and students or learners. The program employs a combination of asynchronous and synchronous modes of delivering lessons in all courses. Further, students can avail themselves of free online materials on farming technologies and 
can study them at their own pace and convenience.

Up until now, no study has been conducted to gather graduates' feedback on the OPAPA E-learning Project. Such information is necessary not only for knowledge generation purposes but also as a guide to improve the program. Data from this study will provide PhilRice with information about how the OPAPA E-learning Project is perceived and whether it is achieving its goals. Results will provide PhilRice information about the relevance of the program to the changing needs of its clientele. PhilRice, as well as its intended clients, will also become aware of the program's weaknesses, and adjust the strategies to accomplish the OPAPA E-learning Project objectives.

This study used the most significant change (MSC) technique described by Davies and Dart (2005). MSC is a participatory technique for monitoring project or program outcomes, since it provides an opportunity for many stakeholders to be involved in deciding the changes to be recorded and analyzed. The use of MSC provides information on impacts and outcomes, which can be highly useful in assessing the performance of the whole program during summative evaluation (Davies and Dart, 2005). As a method for evaluating programs, MSC has been applied in various contexts including farmers' adoption of rainforestation farming (Velarde et al., 2007), practice of sustainable organic agriculture technologies (Corcino and Cagasan, 2011), and adoption of best management practices in forest tree nurseries (Gravoso et al., 2011).

\section{MATERIALS AND METHODS}

\section{Research design and setting}

This study applied the case study research technique. A case study is an in-depth study of a particular situation (Shuttleworth, 2008). Its strength lies in its ability to 'provide an opportunity to highlight a project's success, or to draw attention to a particular challenge or difficulty with a project (Neale et al., 2006). Case studies allow the researcher to present data collected from multiple methods, including interviews, observation and document review.

Data were gathered from 20 OPAPA graduates composed of students of a state college, farmers who were members of a cooperative, and extension workers. Study sites were the town of Magalang in Pampanga and in two cities of Nueva Ecija, namely Cabanatuan City and the Science City of 


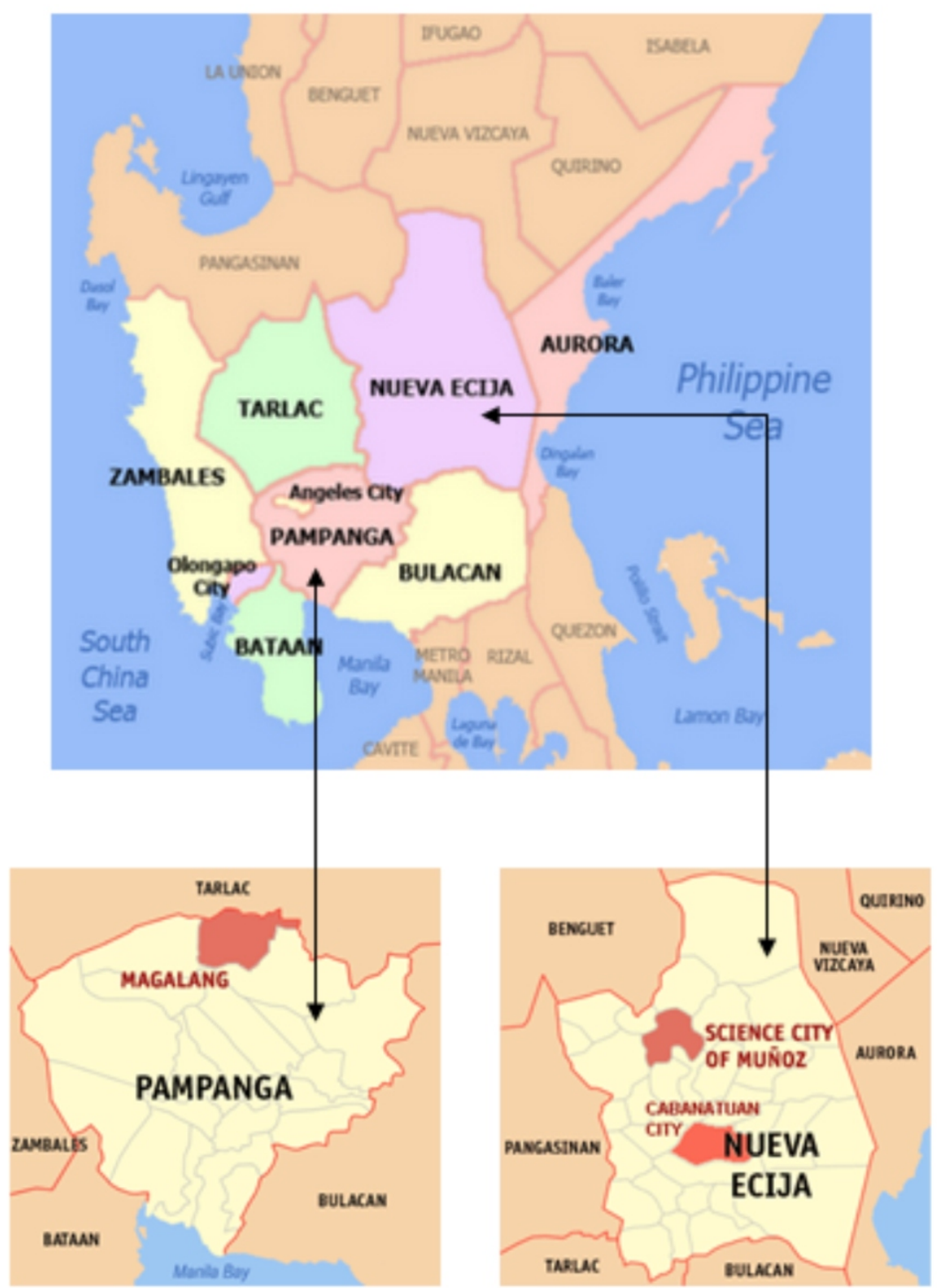

Figure 1 . The study sites 
Muñoz. Both provinces are located in Central Luzon (Fig. 1). These sites were chosen because the majority of the graduates were residing in these areas, and contact with the office of OPAPA was easy since the Philippine Rice Research Institute is located in the Science City of Muñoz in Nueva Ecija. The respondents constituted about one-third (33.4\%) of the total OPAPA graduates up to the time when the study was conducted.

With the assistance of OPAPA personnel, letters of notice were sent to agencies and to organizations with which respondents were affiliated. Interviewing commenced after obtaining a written consent from the respondents.

\section{Data gathering instrumentand procedure}

The main data gathering instrument was an in-depth interview guide. The respondents were asked about their socio-demographic characteristics, sources of information about the project, their reasons for enrolling, feedback on the project and the most significant changes they have experienced after graduating from the OPAPA E-learning Project. The steps described by Davies and Dart (2005), as presented visually in Figure 2, were applied.

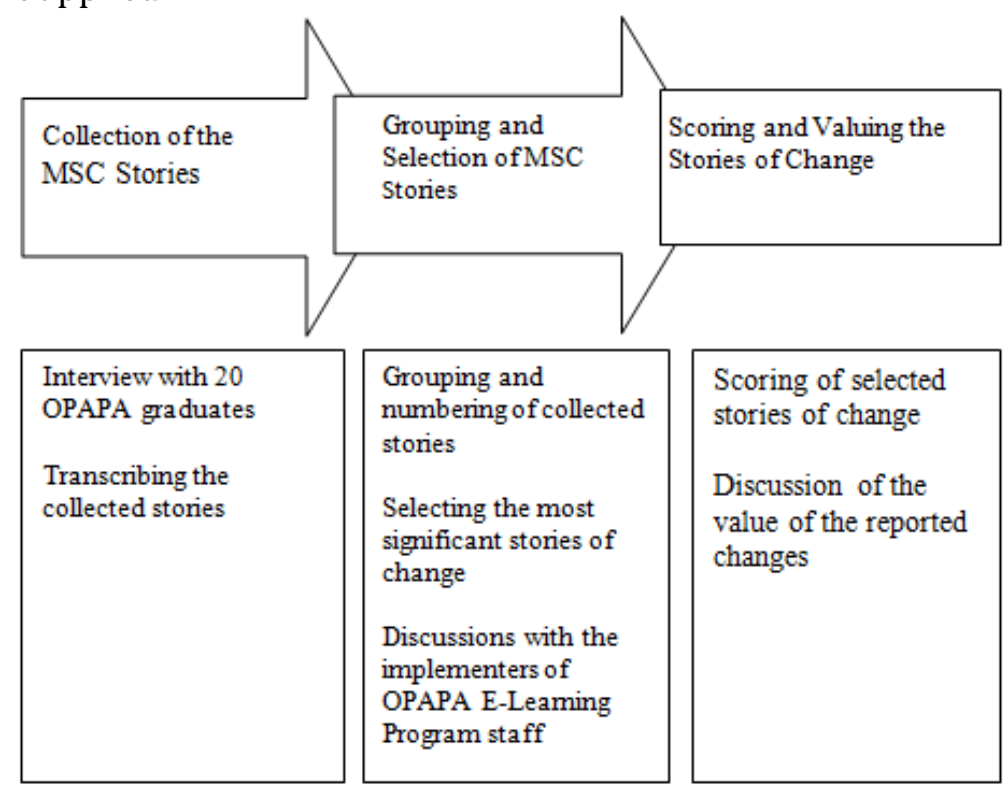

Figure 2. Steps of the most significant change technique as used in this study (adapted from Davis and Dart, 2005) 
Collecting the stories. In this step, each of the 20 graduates was asked to tell stories about what they considered as most significant changes they experienced after graduating from the OPAPA E-learning Project. In telling their story, each respondent was allowed to use any language or dialect with which they were comfortable. The stories were recorded on a MP3 and later transcribed verbatim.

Grouping of collected stories. Recorded stories were read and grouped according to the domains of change. Based on the stories, the domains of change that emerged were: 1 ) increase in knowledge of rice technologies and awareness of the OPAPA E-learning Project; 2) improved school and extension performance, and increased farm productivity; and 3) enhanced computer skills. After the grouping and numbering of the stories, the most significant change stories were selected.

Scoring of selected stories and analyzing the value of the reported changes. In this step, a final meeting was conducted with the head and other OPAPA staff, including the E-Learning specialist (the focal person of OPAPA). In this meeting, scoring of selected stories of change was conducted. A scale of 1 (for least significant) up to 5 (for most significant) was used. This was a one-off exercise wherein each of the staff came up with their own ratings. For stories that were rated differently, a consensus was met through staff discussion and agreement. In this meeting, the importance of the reported changes was also discussed to determine the most significant change stories.

\section{Data Interpretation}

The most significant change stories were subjected to a thematic analysis using the domains of change as framework and were then presented in narrative form. Likewise, frequency counts were made of the stories in each change domain. Bennett's Hierarchy of Program Outcomes (Table 1) was used as guide to determine the level of program outcomes.

In this study, to determine the outcome levels of OPAPA E-learning Project, the stories were transcribed and read, and outcomes in each story were noted using a checklist. Each story did not necessarily fall in only one outcome group, but could also illustrate other outcomes in the hierarchy. 
Table 1. Levels of program outcomes based on Bennett's Hierarchy of Programe

$\begin{cases}\frac{\text { Outcomes (de los Santos (1992) }}{\text { Level }} \\ \hline \text { Outcomes } & \text { Description } \\ \hline 7 & \text { Consequences for society and consequences for the target group } \\ 6 & \text { Behavioral changes in the target group } \\ 5 & \text { Changes in knowledge, attitude, skills, aspiration and group norms } \\ 4 & \text { The students' opinion in extension activities } \\ \hline \text { Inputs } & \\ \hline 3 & \text { Students' participation in extension activities } \\ 2 & \text { Implementation of the program by implementers } \\ 1 & \text { Programming of extension activities } \\ \hline\end{cases}$

\section{RESULTS AND DISCUSSION}

\section{Respondents' Background Profiles}

Table 2 summarizes the respondents' background profiles. Based on the age classification by Talbot et al. (2005), 12 respondents were in the middle age group, while 8 belonged to the young group. Based on the data, the age range was 20-64 (M=43, SD=15.71).

Table 2. Socio-demographic characteristics of the respondents

\begin{tabular}{ll}
\hline \multicolumn{1}{c}{ Variables } & Number \\
\hline Age $^{*}$ & \\
Young (20-45 years old) & 8 \\
Middle age (46-65 years old) & 12 \\
Total & 20 \\
Educational Attainment & 1 \\
Completed Elementary Level & 8 \\
$\quad$ College Student & 9 \\
College Graduate & 2 \\
MS Graduate & 20 \\
Total & 7 \\
Occupation & 10 \\
Student & 3 \\
Extension agent & 20 \\
Farmer & \\
Total & 14 \\
Sex $\quad$ Male & 6 \\
Female & 20 \\
Total & \\
Civil Status & 7 \\
Single & 13 \\
Married & 20 \\
Total &
\end{tabular}


In terms of educational attainment, nine of the respondents had graduated from college, while eight were still studying for their college degree. Two had completede a master's degree. One respondent completed an elementary education only.

Half of the respondents (10) were agricultural technologists (ATs). Seven were students and three were farmers. Of the total number of respondents, 14 were male and six were female. Seven were single (mostly students) and the remainder were currently married.

\section{Reasons for Enrolling in the Program}

Table 3 presents the summary of the reasons for enrolling the OPAPA Elearning Project. The reason 'to acquire additional knowledge of farming technologies' is contained in the phrases, to gain additional knowledge, to learn something, and to gain knowledge. Nine of the respondents gave this reason for enrolling in the program, for example:

"Of course, we got interested in the OPAPA E-learning Project because it's somehow related to our field of work. If farmers have queries, we can answer them well and hopefully provide solutions. That's why we really wanted to learn the topics taught in the program." [ Respondent\#3]

According to the ATs, they enrolled in the program to learn new things, including use of computers, the Internet, and to become computer literate. They said that when ATs have information technology skills, they are no longer considered as low-tech persons. A statement from an extension worker in Muñoz captures this reason:

"First and foremost, I'm really interested in learning how to operate a computer. Of course, at first I was afraid; I didn't know how to use it. It was also the reason why I asked my grandson to teach me; he knows a lot about computer compared to a master's graduate like me. My major reason was realy for me to know how to operate and use the computer." [ Respondent \#5]

To gain up-to-date information on new farm technologies and techniques that can be applied in the farming practice was the reason given by four respondents. According to them, they wanted to gain up-to-date

In this study, the term Agricultural Technologists (ATs) refers to extension workers. Their main responsibility is to promote technology adoption among the farmers 
Table 3. Respondents' reasons for enrolling in the OPAPA E-Learning Project

\begin{tabular}{ll}
\hline Reasons for Enrolling & \multicolumn{1}{c}{ Explanation } \\
\hline To acquire additional knowledge of & Respondents were very interested to learn more \\
farming technologies & about the topics offered by the program. \\
& $\begin{array}{l}\text { Respondents wanted to increase their knowledge } \\
\text { of the various farm techniques by enrolling in the } \\
\text { program. }\end{array}$
\end{tabular}

To gain skills in operating or using computer

To be updated about new farm technologies that can be applied in the field

To fulfill an academic requirement

To acquire new experience

To comply with work requirement

\begin{abstract}
Respondents were interested and very willing to learn how to operate a computer. This gave them an edge not just in their personal development, but in their work and in their studies as well. Their know-how in the new technologies like the computer will give them an opportunity to be part of the modern generation.
\end{abstract}

Respondents wanted to be updated about the new trends, farm techniques and/or technologies which can be applied in the field.

Students who enrolled in the E-Learning Project said that their participation in the OPAPA ELearning was part of their academic program. According to them, the E-Learning Project was beneficial because it provided them with an opportunity to learn the topics in advance.

Respondents enrolled in the program because of their curiosity, considering that the program is a new agriculture-related project.

Respondents enrolled in the program because their office head or supervisor encouraged them to do so.

knowledge about new farm technologies, which can be applied in the field. An example of this reason is from a farmer who said that he enrolled in the program to gain new knowledge. He said that farming is his only means of livelihood, so he always seeks for new farming technologies.

The students in this study reported that they enrolled in the program to fulfill an academic requirement. During the conduct of the study, these students were still undertaking an agricultural science program in a state college. Aside from the agricultural sciences courses, these students were enrolled in other courses, including economics, business and English, as required by the Philippine education system. According to them, their instructor in an agricultural science course told them about the OPAPA E- 
learning Project and encouraged them to enroll. Since the lessons were related to their course on agriculture, they decided to enroll. A quote that captures this is from a student who said:

"It's really very useful for us since we are taking a subject on agronomy. So we really needed it. I wasn't forced to enroll. The advantage is that, I am ahead compared to the rest of the class. My participation in the program was really for academic purposes. I would also need to enroll in the postharvest module." [Respondent\#10]

Five of the respondents said that they enrolled in the program because they were curious and for them to get a new experience as well. According to the respondents, they enrolled because they wanted to gain additional experiences. As one respondent put it,

"I had no special reason for enrolling but I just felt good that we were able to experience it [online learning]. We were always thrilled to know our scores in the test. It was really a nice experience. We learned that despite our age, we can still be computer literates" [Respondent \#4].

Two of the respondents enrolled in the programe because it is required in their present job. As one respondent explained, "Our office required us to enroll in the program. In a sense, I was forced to participate since it was required by my work" [Respondent\#2].

\section{Most Significant Change Stories}

Eight of the 20 stories were rated by OPAPA staff as the most significant of all changes. Two stories each were classified under the first and second domains, and four under the last domain (Table 4).

Domain 1: Increase in knowledge of rice technologies and awareness of the OPAPA E-learning Project. This domain is based on the story of seven respondents who considered that a significant change that happened to them as an E-Learning graduate was the increase in their knowledge about the topic on MOET and Rice Post-production Technologies, and awareness of the existence of such a program. Both the stories of agricultural technologists of the City Agro-Industry and Cooperative Office (CAICO) of Cabanatuan City were chosen as the most significant change stories under this domain. The staff chose the stories because these emphasized how 
their knowledge has increased after they participated in the program and how the program made a great contribution on their acquired knowledge. The two stories were chosen because these illustrated interests in the program itself.

Table 4. Stories selected by OPAPA staff according to domains of change

\begin{tabular}{lll}
\hline Domain of Change & \multicolumn{1}{c}{ Title of the Story } & \multicolumn{1}{c}{ Explanation } \\
\hline $\begin{array}{l}\text { Increase in knowledge of } \\
\text { rice technologies and }\end{array}$ & Capable of Sharing & $\begin{array}{l}\text { This domain is based on the story of } \\
\text { awareness of the OPAPA }\end{array}$ \\
$\begin{array}{l}\text { E-learning Project } \\
\text { Never been this }\end{array}$ & $\begin{array}{l}\text { that the big change that happened to } \\
\text { them as an E-Learning graduate was } \\
\text { the increase in their knowledge } \\
\text { about the topic and awareness of the } \\
\text { existence of such program. }\end{array}$
\end{tabular}

Improved school and extension performance and increased farm productivity

Ever Increasing Harvest

An AT Who Teaches

Enhanced computer skill

A Modern Farmer

A Proud AT.

Widened Knowledge

A Person Who Now Knows How To Use the Internet
In this domain, respondents told their experiences how the program improved their performance in school, farm and in their job as ATs. Of the eight stories under this domain, two were selected as the most significant change story.

In this domain, respondents emphasized that the significant change they have experienced is the improvement of their computer literacy. Five stories were classified under this domain. Four of which were identified as the most significant change stories.

The stories indicate that the E-Learning Project of OPAPA was able to facilitate the needs of ATs for information through the use of ICT in the field of agricultural extension activity. Because one of the goals of OPAPA is to educate and train farmers and extension workers through the use of ICT and distance learning, this is an indication of how the program contributed to the changes experienced by the respondents. 
Domain 2: Improved school and extension performance and increased farm productivity. In this domain, respondents reported their experiences about how the program improved their performance in school, on farms and in their work as agricultural technologists. Of the eight stories under this domain, two were selected as the most significant change stories.

The significant stories show that the program had great influence in the lives of the respondents through the knowledge and information imparted to them. This information was also able to help respondents improve their farm and extension practices. The use of ICT in agricultural extension, can therefore provide essential information and significant change to a community of diverse agriculture practitioners.

Domain 3: Enhanced computer skill. In this domain, respondents emphasized that the significant change they have experienced is the improvement of their computer literacy. Five stories were classified under this domain, four of which were identified as the most significant change stories. These stories were shared by one farmer and three extension workers. All of them emphasized how the program changed them into computer literate farmer and extensionists. According to them, they were never exposed to computers until they attended the basic ICT training and enrolled in the program. They said that for them, preparing reports is now faster, thus they are able to submit reports earlier than the deadline. Through their computer skills, the ATs are also able to obtain more information that they can disseminate to respond to farmers' problems.

\section{Levels of Program Outcomes}

To assess the levels of the E-Learning Program outcomes, the changes contained in the stories were classified according to Bennett's Hierarchy of Program Outcomes. The results are summarized in Table 5.

Bennett's Hierarchy of Program Outcomes contains two major components, inputs to a program and outcomes related to those inputs (de los Santos, 1992). Contained within the inputs component are three separate ordered categories, namely programming of extension activities, implementation of the program by implementers, and students' participation in extension activities. On the other hand, outcomes were measured not through the pre-identified indicators but by the stories from the graduates through the MSC process. The changes described by clients correspond to the outcome categories of the hierarchy. 
Table 5. Levels of OPAPA E- learning Project Outcomes

\begin{tabular}{|c|c|c|}
\hline Levels of Outcomes & Themes of Change & $\begin{array}{c}\text { Number of } \\
\text { Stories }\end{array}$ \\
\hline \multirow{4}{*}{$\begin{array}{l}\text { 3) OPAPA E-Learning } \\
\text { graduates' participation in } \\
\text { the program }\end{array}$} & \multirow{2}{*}{$\begin{array}{l}\text { Involvement of respondents in the program } \\
\text { through participation of basic ICT training }\end{array}$} & 8 \\
\hline & & 5 \\
\hline & $\begin{array}{l}\text { Involvement of respondents in the program } \\
\text { through recommendation }\end{array}$ & 7 \\
\hline & Sub-total & 20 \\
\hline \multirow{4}{*}{$\begin{array}{l}\text { 4) OPAPA E-Learning } \\
\text { graduates' opinion in the } \\
\text { program }\end{array}$} & \multirow{3}{*}{$\begin{array}{l}\text { Positive feedback to the program such as } \\
\text { perceived relevance of the lessons, comments } \\
\text { on the teachers, usefulness of supplementary } \\
\text { materials, comments on the program as a } \\
\text { whole, and suggestions to improve program } \\
\text { implementation }\end{array}$} & 7 \\
\hline & & 8 \\
\hline & & 5 \\
\hline & Sub-total & 20 \\
\hline \multirow{3}{*}{$\begin{array}{l}\text { 5) OPAPA E-Learning } \\
\text { graduates' change in KASA }\end{array}$} & \multirow{3}{*}{$\begin{array}{l}\text { Improved knowledge about rice technologies, } \\
\text { formation of positive attitude towards the } \\
\text { program and improved skill in computer use }\end{array}$} & 7 \\
\hline & & 8 \\
\hline & & 5 \\
\hline & Sub-total & 20 \\
\hline \multirow[t]{6}{*}{$\begin{array}{l}\text { 6) Behavioral changes of } \\
\text { OPAPA E-Learning } \\
\text { graduates' }\end{array}$} & $\begin{array}{l}\text { Change in farm, school and extension } \\
\text { practices; change in information sharing } \\
\text { behavior }\end{array}$ & 4 \\
\hline & \multirow{3}{*}{$\begin{array}{l}\text { Improved capability and confidence to } \\
\text { answer farmers' questions or to answer } \\
\text { teachers questions and to perform extension } \\
\text { functions; }\end{array}$} & 4 \\
\hline & & 5 \\
\hline & & 3 \\
\hline & Improved farm productivity for farmers & 3 \\
\hline & Sub-total & 19 \\
\hline
\end{tabular}

Considering that the goals of the OPAPA are to: 1) educate, train and mobilize the extension workers in agriculture using ICT and distance learning; 2) package available information and farming technologies into relevant electronic or digitized formats for use by all farming stakeholders, and 3) provide extension services, advisory and general knowledge on agriculture to farmers, among others (OPAPA Completion Report, 2008), it can be argued that the OPAPA E-Learning Project is achieving its goals. The 
outcomes may not yet be at the highest level in the heirarchy, but results show that the program has been effective as proven by the outcomes that reached the second highest level. Although the intended clients of the program are extension workers, Bennett's Hierarchy of Program Outcomes also showed that the OPAPA E-Learning Project has achieved its goals for the farmers and students.

\section{Suggestions to improve the program}

While respondents believed that the program is already effective, they still suggested improving it further. Their suggestions are summarized in Table 6.

Table 6. Respondents' suggestions to improve the OPAPA E-learning Project

\begin{tabular}{ll}
\hline Suggestion & \multicolumn{1}{c}{ Explanation } \\
\hline $\begin{array}{l}\text { Establishing a linkage between } \\
\text { PhilRice and the local government } \\
\text { units (LGUs) }\end{array}$ & $\begin{array}{l}\text { Respondents said that establishing linkage between } \\
\text { PhilRice and LGUs is needed so that more farmers } \\
\text { will be able to avail of the OPAPA E-learning Project. }\end{array}$ \\
$\begin{array}{ll}\text { Wider information dissemination } \\
\text { about the program }\end{array}$ & $\begin{array}{l}\text { Respondents underscored the need for wider } \\
\text { information dissemination so that many ATs and } \\
\text { farmers will be able to enroll in it. They said that } \\
\text { information dissemination using IEC materials will } \\
\text { help the OPAPA E-learning Project become known } \\
\text { not just in Central Luzon but also in other regions in } \\
\text { the country. }\end{array}$ \\
& $\begin{array}{l}\text { Respondents suggested the possibility of the } \\
\text { program offering more courses, including courses } \\
\text { offering of more courses }\end{array}$ \\
& which focus on plant diseases. \\
\hline
\end{tabular}

In regard to establishing a linkage with the LGUs, respondents said that such linkage is needed so that more farmers will be able to avail of the program.

Respondents also stressed the need for wider information dissemination so that many ATs and farmers will be able to enroll in it. They said that information dissemination using IEC materials will help the program's popularity throughout the country.

Respondents suggested that the OPAPA E-learning Program offer modules other than the existing ones. One respondent said that, "Other lessons, including plant diseases, should also be offered through OPAPA. Farmers know so much about production technologies but lack technical 
know-how when it comes to control of diseases. If they see any abnormalities in their crop, they immediately get scared. This is because they lack training or information in terms of crop protection." [Respondent \#2].

When asked if they will suggest to their friends to enroll in the OPAPA Elearning Project, almost all (19) answered in the affirmative.

\section{IMPLICATIONS AND RECOMMENDATIONS}

The level of project outcomes as determined through Bennett's Hierarchy of Program Outcomes and the significant change stories narrated by farmers indicated that the OPAPA E-Learning Project is successful in serving as a platform for effective capability development of extension personnel and as a means for hastening information dissemination. The stories that belong to the various domains of change clearly demonstrate this.

The OPAPA E-Learning Project has been proven to be an effective means for developing the capability of extension personnel. According to the ATs included in this study, from their lessons, they have gained confidence in explaining rice technologies to farmers through avenues including farmer-training and the farmer field school.

Looking at the reasons for enrolling in the program, it can be argued that the participation of the graduates included in this study may be accidental. However, considering the benefits they experienced while studying, coupled with the expert teachers and useful supplementary materials, these graduates have been motivated to complete the program. It can be deduced that a learning system like the OPAPA E-learning Project has a greater chance to attract clients' participation if the system is responsive to the needs of the enrollees and that their participation provides them with gratification. Based on the results, enrollees derived gratification from the supplementary materials and the teachers who were experts in the topics and who treated them well throughout the program.

Although not the primary target beneficiaries, college students who enrolled in the program also found the E-Learning Project as useful, and through their participation were more advanced in their lessons compared to their classmates. This finding demonstrates that an ICT intervention like the OPAPA E-learning Project can really help improve the quality of learning in schools. Schools aiming to improve the quality of training of their students may consider integrating the OPAPA E-learning Project into 
their classes.

The OPAPA E-learning Project has yet to reach a greater number of its target clientele. Thus, respondents have suggested that PhilRice forges a linkage with LGUs. The suggestion has merit because with the advent of the Local Government Code, the extension function of these offices has been devolved to the LGUs. At this time, LGUs are in dire need to develop their extension capability at a minimal cost. The OPAPA E-learning Project is a viable answer to this need.

There is also a need to widen the dissemination of the availability of the program so that, aside from the ATs, more farmers and students could avail themselves of the program. The MSC stories gathered in these stories may be used in promoting the program to its intended clients.

This study produced findings that can serve as guide in improving the implementation of the OPAPA E-learning Project. However, there is a dearth of information on the effects of the program at the field level. Thus, further research is recommended. One study that may be pursued is a survey to a wider number of graduates from other parts of the country Records show that the program has graduates in Visayas and Mindanao.

The fact that almost $50 \%$ of the enrollees dropped out of the program suggest the need to investigate the conditions leading to completion of the program. A study that focuses on ICT interventions other than the OPAPA E-learning Project is also needed. At the time of writing, a number of ICT projects are being implemented in developing countries. However, there is a dearth for information about the benefits these programs provide to the clientele. These studies may combine quantitative and qualitative indicators of measuring impacts.

\section{REFERENCES}

ALVIOLA, U.B., and E.G. CAGASAN. 2008. Appropriation of the information and communications technologies by farmers and extension workers in Borongan, Eastern Samar. Annals of Tropical Research, 30(1): 93112.

DAVIES, R. and J. DART. 2005. The 'most significant change' (MSC) technique: A guide to its use. Retrieved September 25, 2009, from: http://www.mande.co.uk 
CORCINO, C. and E.G. CAGASAN. 2011. Significant changes experienced by the adopters of sustainable organic agriculture technologies in Ormoc City, Philippines. Annals of Tropical Research 33(2): 90-100.

DE LOS SANTOS, M. 1992. Use of Bennett's hierarchal model in evaluation of the extension education program for cacao farmers in the Northeast Region of the Dominican Republic. Summary of Research 54(82) :1-10.

GRAVOSO, R.S., N.O. GREGORIO, M.A.D. GERONA, M.N.V. SERINO, S.H. HARRISON, PAJARON, S.H. and J.V. GODOY. 2011. Development and implementation of a nursery accreditation policy at a local level in Leyte, Philippines. Small-Scale Forestry 10(4):473-488.

LIGHTFOOT, C., H. GILLMAN, U. SCHEUERMEIER, and V. NVIMBO. 2008, The first mile Project in Tanzania: Linking Smallholder Farmers to Markets Using Modern Communication Technology. Mountain Research and Development 8(1): 13-17,

INTERNATIONAL INSTITUTE FOR COMMUNICATION AND DEVELOPMENT. 2005. Using ICT in the agricultural livelihoods sector. Retrieved October 17,2009, from: http://www.iicd.org.

NEALE, P., S. THAPA, and C. BOYCE. 2006. Preparing a case study: A guide for designing and conducting a case study for evaluation input. Pathfinder International Tool Series Monitoring and Evaluation 1(1):116.

OPEN ACADEMY FOR PHILIPPINE AGRICULTURE. 2008. Completion Report 2008. Paper submitted to the K-Agrinet Project Management Office. Science City of Muñoz, Nueva Ecija: Open Academy for Philippine Agriculture.

RICHARDSON, D. 1998. The Internet and rural development. In: The first mile of connectivity: Advancing telecommunications for rural development through participation communication approach (D. Richardson \& L. Paisely, eds) Food and Agriculture Organization. Rome, Italy pp. 170-181. 
SHUTTLEWORTH, M. 2008. Case study research design. Retrieved December 17, 2009 from http://www.experiment-resources.com.

TALBOT, L.A., R.J. MUSIOL, E.K., WITHAMS, E.J. METTER. 2005. Falls in young, middle-aged and older community dwelling adults: Perceived cause, environmental factors and injury. BMC Public Health 5:86.

THAS, A. and L. SIMERSKA. 2006. Evaluation of gender for agriculture and rural development in the information society (GenARDIS)-Phases I and II. Summary of Key Findings \& Recommendations. Retrieved October 19, 2009 from http://www. genardis.apcwomen.org.

VELARDE, G.L., R.S. GRAVOSO, E.G., CAGASAN, and GABRILLO, C.A. 2007. Most significant changes experiences by farmers from adopting rainforestation farming. Annals of Tropical Research 29(3):109-122. 